\title{
A Review on the Application and Benefits of Probiotics Supplements in Fish Culture
}

\author{
Eyo Victor Oscar*, Eriegha Ochuko Joshua, Eze Felix and Awvemoya Fred Eyerituvie \\ Department of Fisheries and Aquaculture, Nigeria Maritime University, Nigeria
}

Submission: December 06, 2019; Published: January 17, 2020

Corresponding author: Eyo Victor Oscar, Department of Fisheries and Aquaculture, Faculty of Marine Environmental Management, Nigeria Maritime University, Okerenkoko, Delta State, Nigeria

\begin{abstract}
Probiotics are supplements that impose health benefits to the host fish when applied at the right amount. Probiotics stabilizes the microbial population of the fish's gastrointestinal tract through elimination of pathogenic microbes and increased digestibility and bioavailability of nutrients required for optimal growth and good health. Fish farmers and fish consumer also benefits from probiotics application in several ways such as improved growth, carcass and flesh quality, boosting of immune system, high survival rate and reduced malformations. Farmers should be encouraged to include probiotics in feed in order to enjoy the corresponding benefits it presents

Kewords: Probiotics; Supplement; Benefits; Aquaculture
\end{abstract}

\section{Introduction}

As aquaculture continues to be intensified globally, new innovations and biotechnologies have been introduced to economically boost aquaculture production which is more peculiar to countries with shortfall of fish supply from the wild. One of such biotechnology is probiotics supplements which is beneficial in different areas of aquaculture. Generally, probiotics is a term that is used to signify bacteria that beneficially promote the health status of other organisms [1]. To World Health Organization, probiotics is defined as live microorganisms that confer health benefit on the host when administered in adequate amounts [2]. The application of probiotics in the rearing water is noted by Luazon et al., [3] to complicate the definition process since it is like terms such as bioaugmentation, biocontrol and bioremediation. Maeda et al., [4] and Moriarty [5] suggested that microbes that are antagonistic to aquatic pathogens, but not found in the host's gastrointestinal tract, should be termed biocontrol agents. Similarly, termed the application of aquatic microbes to improve water quality by breaking down of waste or pollutants as bioaugmentation or bioremediation [5-7]. Based on these observations, Merrifield et al., [8] proposed a broader and classical definition of probiotics intended for use in aquaculture as 'any microbial cell provided via the diet or rearing water that benefits the host fish, fish farmer or fish consumer, which is achieved, in part at least, by improving the microbial balance of the fish'.
The need for alternative prophylactic methods needed to remedy the survival issues faced at different stages of intensive rearing activated research on probiotic microorganism's application in aquaculture. According to Lauzon et al., [3] probiotics are increasingly accepted as an alternative prophylactic measure for both animals and humans, either to be used in preventive treatments or in the treatment of pathogen-related diseases. According to FAO [9], fish and other aquaculture products provides a very useful source of essential micronutrients and protein needed for good health and balanced nutrition worldwide. With the world population expected to grow annually at a rate of $1.6 \%$ there is an indication of a possible shortage in food supply especially protein sources. To meet up the demand of fish protein for the growing global population, aquaculture remains one of the most economic and reliable option for sustainable fish supply [10-12]. However, there is need for an environment friendly aquaculture production system. The use of probiotics supplement in aquaculture is now gaining popularity to increase safety and high-quality protein production for both human and livestock instead of chemotherapy and antibiotics. Therefore, the aim of this mini review paper is to evaluate the application and benefits of probiotics supplements in aquaculture.

\section{Application of Probiotics in Aquaculture}

According to Macey and Coyne [13], probiotics usage in culture of aquatic organisms has been very effective in improving growth, 
disease resistance and nutrition. Traditionally, probiotics were incorporated into animal feed to boost the growth performance, disease resistance and health [14]. In aquaculture, probiotics can be used in aquaculture either as an additive to the water to enhance quality or feed supplement to enhance growth, health and disease control resulting in the improvement of fish welfare [15].

\section{Mode of Action of Probiotics Application in Aquaculture}

Several studies have been focused on growth promotion, physiological as well as immune responses of fish exposed to probiotics supplements [16]. However, these is only possible if the modes of action of probiotics are clearly understood. There are four modes of action exhibited by probiotics in aquaculture [17] which include:

i. Competitive exclusion of pathogenic (disease causing) bacteria through nutrient and habitat competition and alteration of pathogen's enzymatic activities.

ii. Improvement of water quality

iii. Enhancement of immune response

iv. Enhancement of host nutrition.

\section{Some common Probiotics used in Aquaculture}

Some common probiotics applied and studied in aquaculture include microorganisms, such as Alteromonas, Aeromonas, Arthrobacter, Bacillus, Clostridium, Debaryomyces Enterobacter, Flavobacterium, Lacto Acid Bacteria, Micrococcus, Phaeobacter, Pseudoalteromonas, Pseudomonas, Roseobacter, Shewanella, Saccharomyces and Vibrio species [8,18-20].

\section{Benefits of Probiotics in Aquaculture}

The benefits of probiotics usage in aquaculture cannot be overemphasized. Several authors such as Qi et al., [21], Wang and Gu [22], Soundarapandian et al., [23], Faramarzi et al., [24], Ngan and Phu [25], Mohapatra et al., [26], Peterson et al., [27] and Nimrat et al., [28], have highlighted the benefits of probiotics in aquaculture as summarized below:

- Promotes appetite resulting in a better food utilization

- Improve feed conversion efficiency (FCE) and feed conversion ratio (FCR).

- Improves feed digestibility and bioavailability of nutrients.

- Stimulate the uptake of dissolved organic material (bacteriamediated)

- Boost immune system thereby reducing disease outbreaks

- Enhance growth performance

- Improves water quality
- $\quad$ Stabilize the intestinal bacterial group

- $\quad$ Reduced mortality

- Stress alleviation

- Improved carcass and flesh quality

- $\quad$ Reduced malformations

\section{Criteria for Probiotic selection}

For a microorganism to be selected as probiotics for use in aquaculture, two categories of criteria including essential (E) and favorable (F) given by Merrifield et al., [8] should be considered:

\section{Essential Criteria (E)}

i. Must not be pathogenic, with regards to the host species, aquatic animals in general and human consumers.

ii. Must be free of plasmid-encoded antibiotic resistance genes.

iii. Must be resistant to bile salts and low $\mathrm{pH}$.

\section{Favorable Criteria (F)}

i. Should be able to colonize the intestinal epithelial surface.

ii. Should be recognized as safe for use as a feed additive.

iii. Should be able to adhere to and/or grow well within intestinal mucus.

iv. Should display advantageous growth characteristics (e.g. a short lag period, a short doubling time and/or growth at host rearing temperatures).

v. Should be indigenous to the host or the rearing environment.

vi. Should produce relevant extracellular digestive enzymes (e.g. chitinase if chitin-rich ingredients are to be incorporated into the diet, or cellulase if the diet is rich in plant ingredients) and/or vitamins.

vii. Should exhibit antagonistic properties towards one or more key pathogens.

viii. Should remain viable under normal storage conditions and be robust enough to survive

industrial processes.

\section{Conclusion}

Probiotics application in aquaculture is of great benefit to the host fish, fish farmer or fish consumer in several ways. Importantly, probiotics stabilizes the microbial population of the fish's GI tract through elimination of pathogenic microbes and increased digestibility and bioavailability of nutrients required for optimal growth and good health. Farmers should be encouraged to include probiotics in feed in order to enjoy the corresponding benefits it presents. 


\section{References}

1. Balcázar JL, de Blas I, Ruiz-Zazuela I, Cunningham D, Vandrell D, et al. (2006) The role of probiotics in aquaculture. Veterinary Microbiology 114(3-4): 173-186.

2. FAO/WHO (2002) Joint FAO/WHO Working Group Report on Drafting Guidelines for the Evaluation of Probiotics in Food, London, Ontario, Canada.

3. Lauzon HL, Dimitroglou A, Merrifield DL, Ringo E and Davies SJ (2014) Probiotics and Prebiotics: Concepts, Definitions and History. Aquaculture nutrition: gut health, probiotics, and prebiotics.

4. Maeda M, Nogami K, Kanematsu M and Hirayama K (1997) The concept of biological control methods in aquaculture. Hydrobiologia 358(1-3): 285-290.

5. Moriarty DJW (1998) Control of luminous Vibrio species in penaeid aquaculture ponds. Aquaculture 164(1-4): 351-358.

6. Moriarty DJW (1997) The role of microorganisms in aquaculture ponds. Aquaculture 151(1-4): 333-349.

7. Gatesoupe FJ (1999) The use of probiotics in aquaculture. Aquaculture 180(1-2): 147-165.

8. Merrifield DL, Dimitroglou A, Foey A, Davies SJ, Baker RTM, et al (2010) The current status and future focus of probiotic and prebiotic applications for salmonids. Aquaculture 302(1-2): 1-18.

9. FAO (2014) The state of the world fisheries and aquaculture. In: Rome, Pp. 106.

10. Eyo VO and Akanse NN (2018) Comparative Study on the Condition Factor, Hematological and Serum Biochemical Parameters of Wild and Hatchery Collected Broodfish of the African Catfish Heterobranchus longifilis (Valenciennes 1840). Asian Journal of Advances in Agricultural Research 5(4): 1-8.

11. Eyo VO and Ivon EA (2017) Growth performance, survival and feed utilization of the African Catfish Heterobranchus longifilis (Valenciennes, 1840) fed diets with varying inclusion levels of Moringa oleifera leaf meal (MLM). Asian Journal of Biology 4(1): 1-10.

12. Eyo VO, Ekanem AP and Jimmy UU (2014) A comparative study of the gonado-somatic index (GSI) and gonad gross morphology of African catfish (Clarias gariepinus) fed Unical aqua feed and Coppens commercial feed. Croatian Journal of Fisheries 72: 63-69.

13. Macey BM and Coyne VE (2005) Improved growth rate and disease resistance in farmed Haliotis midae through probiotics treatment. Aquaculture 245: 249-261.

14. Lara-Flores M, Olvera-Novoa MA, Guzman-Mendez BE, and López-Madrid W (2003) Use of the bacteria Streptococcus faecium and Lactobacillus acidophilus, and the yeast Saccharomyces cerevisiae as growth promoters in Nile tilapia (Oreochromis niloticus). Aquaculture 216: 193-201.

15. Moriarty DJW (1999) Disease control in shrimp aquaculture with probiotic bacteria. In: C R Bell, M Brylinsky and P Johnson-Green (Eds.)
Microbial biosystems: New frontiers. Proceedings of the 8th International Symposium on Microbial Ecology. Atlantic Canada Society for Microbial Ecology, Halifax, Canada.

16. Akinbowale OL, Peng H, Barton (2006) Antimicrobial resistance in bacteria isolated from aquaculture sources in Australia. J Appl Microbiology 100: 1103-1113.

17. Verschuere L, Rombaut G, Sorgeloos P, Verstraete W (2000) Probiotics bacteria as biological control agents in aquaculture. Microbiol Mol Bio Rev 64(4): 655-671.

18. Lauzon HL (2010) Preventive measures in aquaculture: isolation, application and effects of probiotics on Atlantic cod (Gadus morhua L.) rearing at early stages. Thesis for the Degree of Philosophiae Doctor in Biomedical Science, University of Iceland, Pp. 194.

19. Prado S, Romalde JL and Barja JL (2010) Review of probiotics for use in bivalve hatcheries. Vet Microbiol 145: 187-197.

20. Dimitroglou A, Merrifield DL, Carnevali O, Picchietti S, Avella M, et al. (2011) Microbial manipulations to improve fish health and production: a Mediterranean perspective. Fish Shellfish Immunol 30(1): 1-16.

21. Qi ZZ, Zhang XH, Boon N and Bossier P (2009) Probiotics in aquaculture of China, current state, problems and prospect. Aquaculture 290: 15-21.

22. Wang YB and Gu Q (2010) Effect of probiotics on white shrimp (Penaeus vannamei) growth performance and immune response. Marine Biology Research 6: 327-332.

23. Soundarapandian P, Ramanan V and Dinakaran GK (2010) Current probiotics bacterium Lactobacillus rhamnosus against experimental Edwardsiella tarda infection in tilapia (Oreochromis niloticus). Veterinary Immunology and Immunopathology 113(3-4): 339-347.

24. Faramazi M, Kiaalvandi S, Lashkarbolooki M and Iranshahi F (2011) The investigation of Lactobacillus acidophilus as probiotics on growth performance and disease resistance of rainbow trout (Oncorhychus mykiss). American-Eurasian Journal of Scientific Research 6(1): 32-38.

25. Ngan PTT and Phu TQ (2011) Effects of Bacillus bacteria (B8, B37, B38) on water quality of black tiger shrimp (Penaeus monodon) cultured tanks. Proceedings of the 4 th Aquaculture and Fisheries Conference 28-41.

26. Mohapatra S, Chakraborty T, Prusty AK, Das P, Paniprasad K, et al. (2012) Use of probiotics in the diet of rohu, Labeo rohita fingerlings: effects on growth nutrient digestibility, retention digestive enzyme activities and intestinal microflra. Aquaculture Nutrition 18: 1-11.

27. Peterson BC, Booth NJ and Manning BB (2012) Replacement of fish meal in juvenile channel catfish, Ictalurus punctatus, diets using a yeast-derived protein source: the effects on weight gain, food conversion ratio, body composition and survival of catfish challenged with Edwardsiella ictaluri. Aquaculture Nutrition 18: 132-137.

28. Nimrat S, Suksawat S, Boonthai T and Vuthiphandchai V (2012) Potential Bacillus probiotics enhance bacterial numbers, water quality and growth during early development of white shrimp (Litopenaeus vannamei). Vet Microbiol 159: 443-450. 
This work is licensed under Creative

Commons Attribution 4.0 Licens

DOI: 10.19080/OFOAJ.2020.11.555817
Your next submission with Juniper Publishers will reach you the below assets

- Quality Editorial service

- Swift Peer Review

- Reprints availability

- E-prints Service

- Manuscript Podcast for convenient understanding

- Global attainment for your research

- Manuscript accessibility in different formats ( Pdf, E-pub, Full Text, Audio)

- Unceasing customer service

Track the below URL for one-step submission https://juniperpublishers.com/online-submission.php 